\title{
Theatre audience crisis and suitable solutions
}

\author{
K. A. Abdulkadir \\ Faculty of Education, Koya University, Kurdistan, Iraq
}

\begin{abstract}
The study begins with a brief introduction on how theatre emerged in the world, Kurdistan and Koya city. In the beginning, performances were conducted in the outside of the theatre closed halls, on the streets, at parties, occasions and in schools. It is clear that an important and complementary aspect of theatre performance process is the audience. Therefore, when the performances lack audience attendances, crises emerge. In order to reduce the crisis, return the theatre role and make up the audience with theatre; it is imperative to provide another kind and style of performing which can be done by returning to the natural and primitive style of theatre; street theatre. From this aspect, we need the opinion of people on the issue. Therefore, we have conducted a survey in which 100 people from different walks of life, different genders and ages participated. The survey consisted of some questions in which the participants were asked to tick appropriate choices according to their opinions. After that the results of the survey have been shown. In addition to the survey we have interviewed experts and professionals in the field in order to know their views on the issue. Finally, appropriate solutions have been suggested to solve this crisis.
\end{abstract}

\section{Introduction}

If we look back on the human civilization history like Mesopotamian history in Iraq and pharaohs in Egypt which their era dates back to many centuries BC, the archaeologists, due to their continuous efforts, have been able to discover a theatre stage in Babylon state. Analyzing some hieroglyphic signs, uncovering ancient archaeological sites of Egypt, analyzing Rashid stone and Ermo temple walls are evidence for the beginning of drama and care for arts in this country. Therefore, in some scientist opinion Egyptian theatre is older than Greek theatre "the pharaohs had a kind of activity called religious root which was not very similar to old activities but rather similar to drama. The phenomenon had been 
the same in most of the world's notions [1]. The Greece also had these activities but to the pharaohs they have not gone out of the religious framework. The Greece soon saved these activities from the hands of Kahn and temples. The intelligence of the Greece was in that they were able to return their gods to the human level. That is like humans they make mistakes and commit crimes. That is why theatre has developed and taken roots there. Here we can find that theatre, since the early times, has been cared for and given an important and influential place by the ancient nations of the human history who own the oldest and greatest civilization, invention and pioneering of humanity. The performances staged during that era were conducted in the open places, streets and special theatre halls for example, those theatres that their traces are seen in Greece. Also there had been other performances in the form of wandering theatre in which the performers were travelling to different paces on carriages. That is the performers, to deliver their messages, were going to their audience instead of their audience coming to them. This performance with all its kinds were offered at parties and social-religious occasions "like the two Greek festivals: the first one was related to tragedy and celebrated in the month of Nawroz (March) in spring and the second one was relevant to comedy and celebrated in Rebandan (January) in winter” [2]. Theatre then sparked from Greece to the other countries of Europe, West, and East, Islamic and Arabic world. Sooner or later, with the passage of time and the situation of these countries theatre emerged. Kurdistan like these countries had its part in these impacts. In the end of the nineteenth century and the beginning of the twentieth century a kind of theatre appeared which was performed in the social occasions, homes and hojras in which stories, folk tales of folklore and nationality in a humoristic way, to commemorate and remind people of these activities, were performed. Koya city was one of the cities in which these activities were carried out and was the leader in this field due to the existence of many important places as teahouses, hojras, gathering places, etc.

\section{Theatre and audience}

Here we find that theatre is one of the human necessities that we cannot abandon in our lives; it is not existed without audience since they are complementary. Originally, theatre has been appeared to serve people and life could not move forward without it. In this regard, Shopnhawar says "Those who do not go to theatre are like those who makeup themselves without mirror" [3]. Theatre, with the message it holds, should effect people and try to change their behaviours, actions, and reflect their everyday life; theatre is a humanistic art and does not separate from audiences [4]. The purpose of this art is to change the audiences, their living styles and improving them in life as an artistic act [5]. Theatre is the tool of development and could be used to improve the nation and prosper the country as the well-known Russian writer Maksim Gorki says "Give me a bread and a theatre I will give you a wise nation" [6]. Contemporary theatre tries strongly to provide this relation between the audiences and artistic works since each artistic work out of this relation will lose its price [7]. Some of the theatre 
directors and writers want to mix the audience and their participation in the performance. This could be seen in the public revolutionary theatre in which the audiences participate in the performance. This was clearly appeared by Jan Jack Russo in the $18^{\text {th }}$ century in France, who said: "Perform the theatres under the shining of the sun, let the audiences be the characters, to make life and world the stage of theatre" [8].

\section{The Kurdish theatre and audiences}

The audiences of Kurdish theatre since the beginning of the theatre movement in Kurdistan have warmly welcomed the works of the artists, mixed with the productions. But in this era this warm welcome is not available anymore, the halls are empty at the time of performances (in the two days of performing the play Door in the middle of July 2007 by the well-known artist Kamran Raoof in Hawler, "I saw with my own eyes only 37 people there") [9]. In the same way, during the 80s and the 90s the theatre audiences in Koya were very good; a large number of people were visiting the halls. The main problem of the theatre teams was to provide suitable halls for that huge number of people. In most of the performances the windows and doors of the halls were broken by people and sometimes the play stage filled with people, the play could not be performed; lots of plays were continued for seven days. But after the 90s, especially in the new century, the theatre audiences were reduced in unpredictable way and reached the point that the teams were afraid of not having audiences so that they did not dare to perform the plays. One of theatre audiences in Koya who worried by the reduction of theatre audiences says "theatre is a circle material from actors, decors, lights, texts and audiences; all these elements will be prepared for the audience; our last element is the audience which is the main character of the work, but in this play, I felt that there were no enough people, I do not know if it was due to peoples' tiredness since it was the last day of the festival?" [10]. The slaw flow of the audiences to the theatre halls has become a problem that people and theatre are about to separate and its important message could not reach the people despite all the hard works by the staff, all the money spent in the project, and the budgets monthly allocated for the teams. The situation has reached the point that we are about to say that all these are spent for nothing since all the performances in Koya lasts for only one or two days. During this time 100 to 200 people will attend the performance and the middle rate will be 70 to 90 people. I was present in the second day of a play in which only 10 people were attended. What are the suitable solutions to reconcile theatre and people and return it to the previous natural situation? In our opinion, the best solution is that we take theatre to the audience since they do not come to theatre; this effective way is to activate the street theatre.

\section{Street theatre}

Street theatre performs its works in wide and open places; it is a type of show and performance in public places. It does not make people to go to the theatre 
halls to see the performances; it has no specific and special audiences in number and type. It could be performed in various places as markets, streets, bus and car stations, public parks, etc.

Street theatre has no united subject to perform but it depends on impulsive method; its subjects are short and refuse details. In America this type of theatre are given more importance and there are writers specific to this type, they know what kind of subjects to write. The actors should be trained for this purpose; makeup, masks and personality are important in this performance. The arrangers and supervisors of this type of plays should be careful about selecting the place and time for the performance, it is better to perform it in a suitable and nice weather away from cold, raining and windy weather and the best seasons are spring, summer and autumn. Also, it is important to choose a specific occasion since people may not gather in a street without purpose, so it is better for the staff to choose the occasions. If there is an occasion and people gathered for this purpose such as celebrating a party in a place, collecting charity for those affected by natural disasters as earthquakes, flood, fire falls, or diseases like HIV, cancer or any other necessary mater needs help; we can think and work for it according to time, era and place since it is an important tool to gather people, giving importance to this performance and delivering the message it holds. It is necessary for us to know that choosing time, place and subject by mistake is the reason that could fail this project.

Street theatre is a tool to spreading intellectuality among community and it is an important gate to reach the individuals, showing the society reality, politics, economics, nationality and intellectuality. The Americans used such theatre in the times of occasions to aware community about the political and social problems, creating a wise and understandable society aware of its rights and duties.

Also, it has been used to return the role of ordinary theatre; inform people about the role of theatre and encourages them to flow into the theatre halls and do not neglect it.

The ordinary or hall theatre has witnessed changes throughout history; it consists of many important elements such as sound, lights, decor, actor, text, director, music, makeup etc., while in the street theatre most of these elements are not existed; these theatres could not replace one another but will be complementary to each other. It is not suitable to reduce the role of any of them for the sake of the other one; they should be performed side by side. The street theatre could be used as a tool to return the audiences to the hall theatres and reconcile people with theatre; it is used as propaganda to show the role of ordinary theatre. In some situations and time the ordinary theatre will have no role and cannot deliver its message, for example in the times of revolutions and disasters due to the change in life generally as what happened in the Arab countries and in Egypt in particular in which people, for more than a month, stayed in the streets, days and nights. In such situation, it is clear that people could not go to the theatre halls and the artists may could not prepare a suitable and serious play and perform it in the halls. The easiest way for such situation is street theatre for that reason the Egyptian artists got use of this street theatre and 
performed several works for their revolutionary people to encourage them to be consistent on revolution and liberation and their rightful demands through showing the roles of revolutionary and national figures; recommending them so that each one knows his duties, rights and roles to protect people, security, and the public wealth because the authorities did not allow them to perform such works in the halls that did not cope with its interests, the supervision committee put many strict limits and obstacles for the works. In this kind of performances there is no need for permission, it needs small expenses and small budgets unlike the ordinary theatre; this clarifies the difference between the two theatres.

\section{The difference between street theatre and ordinary theatre}

Street theatre removes every obstacle in front of actors and audiences; mixing it with the events and subjects and affects them. The audiences and the artists think that theatre is more effective than the TV dramas due to that in theatre both actors and audiences meet and mix one another directly. Here both theatres have differences because there are some obstacles and separations in the ordinary theatre between the sender and the receiver (actors and audiences). But all these will melt and disappear in the street theatre so the sense of feeling one another is more happening. Street theatre is an entertaining tool to gather people who are close to one another and have relations and share something in common such as the housing place (in the same street or neighbourhood) and works (student, employee or worker etc, they will be ready to see the play). Such a kind of theatre has random method which allows them to participate and come inside the events so he will test his likes and ability and enter the reality of the subject; these are neglected in the ordinary theatre.

Some old or isolated neighbourhoods cannot benefit from ordinary theatre in any way so that the works could be transformed through street theatre to these places and care more about these neglected places. Also, the elderly, children, house wives, adults and others from society are away from theatre; they might have not seen two works of ordinary theatre in their lives due to different reasons. In this way, they can benefit from the art of theatre and deliver our messages to them.

Since works are different and people are also different so that their habits, rights, and wishes are not the same. The problem of each street, neighbourhood, organization, and department are different from the other one, so it will be possible to prepare special subjects and personal problems by each of them and shed light on them, then perform them in this place. For example, the problems of university students are different from those of workers, so it is important to talk about student issues when performing the play in the university camp and find suitable solutions for them.

It is possible to encourage people to gather around the theatre through different means and reasons such as using songs in the performance by singers , using and mixing attractive dances by talented people in this respect, using the silent scenes by symbols and signs and body language to show things, using masks in the shape of imaginary personalities or animals, using rare and 
attractive colourful clothes, and wearing high bases as shoes by the actors to show them high and huge and to attract the audiences since this appears as a rare and strange thing. These will help in attracting people to gather around the play and give more importance to the performance.

The crisis facing theatre regarding the shortage in audience in Koya and the big gap between theatre and audience have created unwanted situation by returning back to the past years and the performances of the two decades in the new century. This is clearly realized in the questionnaire conducted for this study; we have distributed 100 forms randomly among different people from both genders in different places in the city which included 7 questions and the results were as the following (Fig. 1):

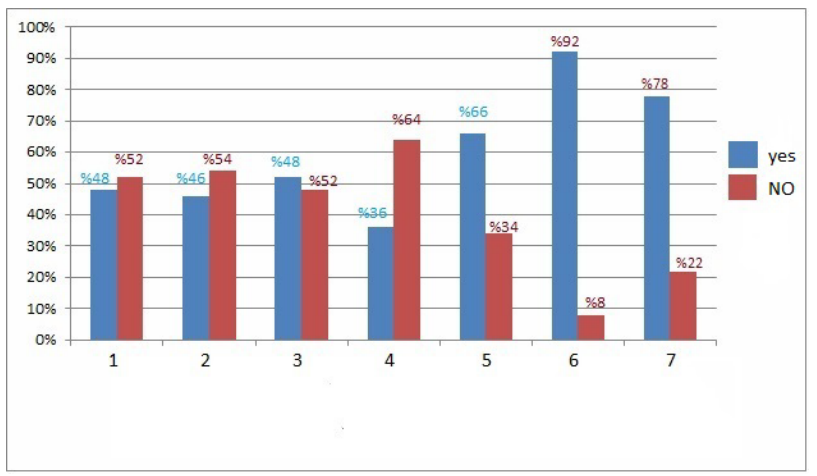

(a)

1-Are you satisfied with theatre in Koya, are the performances performed according to needs?

2-Do you think theatre has played its role in developing and educating the people of Koya?

3-Are you aware of the theatre performances in your city?

4-Do you go to the theatre performances in your city?

5- Do you know the names of theatre teams and the artists in your city (do you know them)?

6-Do you prefer street theatre or ordinary one performed in the halls?

7-Do you prefer the theatre to be performed outside the halls?

(b)

Figure 1: $\quad$ (a) The results of the Questioner; (b) Questions of the Questioner.

The answers of questions $(1,2)$ show that play has been well performed in Koya and had its role for the message it holds to increase the awareness and education of people. The results of questions $(3,4,5)$ show that the play 
propagandas during the performances are useful and most people will be aware about them, but a small number of people are ready to go to the play; those who are ready to go will not always be there and may just see no more than two parts of a work. The answers of questions $(6,7)$ show that most of people agree that it is necessary another type of theatre should be created with different contents and form which is the street theatre. They agree to bring out the plays from the halls and perform them in the schools, public places, factories, neighbourhoods, and universities to form a new educated generation aware of the changes in new literary and artistic messages.

\section{The artists' opinion about the audience crisis}

To clarify the subject we found it suitable to take the opinion of the artists who have worked on both theatres. Their opinions were as the following: for the reconciliation of the theatre audiences and retuning the role of theatre, it is necessary to show these texts which are domestic and social in a comic way. Being away from those texts that are showed just for elite; giving more importance to the street theatre since every one could watch the performance but the chance is not given to everyone to see the plays in the halls except a group of intellectuals who are seen repeatedly there. To pass the current Kurdish theatre situation in Koya, the best solution is to give importance to the street theatre [11].

The street theatre is more important than the ones performed in the halls since the street theatre will have its audience in any way. The people who walk in the streets are tired of being walking and working all the day so they will stay for watching the play and forget their tiredness; at the same time people should dedicate a special time and go to the halls to see the plays. Most of those people are acquaintances of the play staff and the artists themselves; this proves that the play is not performed for all the members of society.

The audiences of the plays in the halls are specific as the artists, educated, and intellectuals. The language of the play is a high literary language while street plays have not specific audiences because most of the members of society see them. Here we find that each type of theatre has its own audience but in general the street theatre has more audience since, in the short time, it could gather a crowd around the play. From this we conclude that street theatre is a necessity of our current days, so it should be given attention as in the other countries [12]. For example street theatre in the world and in the Islamic and Arabic world is given more importance such as in America, France, Egypt, Lebanon, Syria, Iran, etc. In these countries special festivals are arranged yearly for theatre such as Mariwan International Festival for street play. In the southern Kurdistan people are about to understand this necessity and festivals are performed yearly as Darbandikhan International Festival for street theatre which performs its fourth festival this year. It is necessary to transform this experience to all the cities and to show the performance continuously. 


\section{Conclusions and suggestions}

As a result of this short study we reach to that the ordinary theatre is not that importance anymore as it had in the past and people do not flow to the halls to see the plays there. So theatre is in crisis regarding the audiences not in the respect of performance; it is necessary to find an alternative for this crisis. This will be accomplished according to the experts, artists, and people generally by establishing the street theatre, so we do not expect people to come to the halls of performances, we transform it to the street, showing them the messages directly and transforming it to the educational centres and departments to aware people about the changes happening in the world today. This process will be a tool for people to understand the role and the necessity of theatre. It could be used as propaganda to return the audience of theatre to the halls; both theatres are important; none of them will reduce the role of the other, both are complementary and work for one common goal.

\section{References*}

[1] Kaniaw, Cinema and Theatre Magazine, A beginning for rewriting the history of Kurdish Theatre, issue no. 7, Hawler, 2000, page 15.

[2] Yousif Zaabalawi, Karwan Magazine and Himat Kakai, Directorate of Culture and Art, issue no. 118, Hawler, 1998, page 101.

[3] Omari Ali Ameen, Theatre in its Audiences View, first edition, Sulaimani, 2003, page 10 .

[4] Ziad Kareem, Raman Magazine, Theatre and Audience Presence, cultural and Publishing Organization of Gulan, issue no. 10, Hawler, 1997, page 35.

[5] Yasin Qadir Barzinji, Theatre Magazine, Theatre...a place for living, Salar Play Team, issue no. 14, 2009, page 14.

[6] Sami Khshba, The Modern Crisis in Theatre, Publisher of Republic, Baghdad 1972, page 203.

[7] Sami Khshba, The Modern Crisis in Theatre, Publisher of Republic, Baghdad 1972, page 56.

[8] Dr. Farhad Perbal, Theatre Magazine, Door Players, Salar Theatre Team, issue no. 5, Sulaimani 2007, page 25.

[9] Dr. Hersh Mohammed, Alai Azadi Newspaper, how I saw a theater of Koya, issue no. 490, Monday 11/11/2002, page 8.

[10] An Interview with Theatre Director Faraidoon Hamadmeen, Koya, Artists Syndicate Office, 1/8/2013, time 5 pm.

[11] An Interview with Theatre Director Hunar Tahir, Koya, Artists Syndicate Office, 1/8/2013, time $6 \mathrm{pm}$.

[12] People Questionnaire.

*All References originally were in Kurdish 